\title{
PEMBANGUNAN KAWASAN EKONOMI MASYARAKAT (KEM) PERTAMINA FLIP DI KELURAHAN SIMPANG TIGA: AKTUALISASI CORPORATE SOCIAL RESPONSIBILITY (CSR) OLEH PT. PERTAMINA (PERSERO) MARKETING OPERATION REGION (MOR) I - TERMINAL BAHAN BAKAR MINYAK (TBBM) SEI SIAK
}

\author{
Fahmy Syahputra $^{1^{*}}$, Rosnelli $^{1}$, Bagoes Maulana ${ }^{1}$, Enny Keristiana Sinaga ${ }^{1}$, Suhairiani $^{1}$ \\ ${ }^{1}$ Fakultas Teknik, Universitas Negeri Medan, Medan, Indonesia \\ "Penulis Korespondensi: famybd@unimed.ac.id
}

\begin{abstract}
Abstrak
Studi ini mengkaji secara deskriptif tentang aktualisasi CSR oleh PT. PERTAMINA (Persero) MOR I - TBBM Sei Siak pada pengembangan KEM di Kelurahan Simpang Tiga Kota Pekan Baru. Tujuan utama dari kegiatan ini adalah membantu anggota Kelompok Tani Juara dalam mengelola lahan marjinal yang ada di Kelurahan Simpang Tiga di Kota Pekan Baru menjadi lahan yang bernilai ekonomi tinggi. Pembentukan Kawasan Ekonomi Masyarakat diharapkan dapat meningkatkan perekonomian keluarga Kelompok Tani Juara. Saat ini pengelolaan lahan pertanian sudah pada tahap pembersihan lahan dan penanaman bibit cabe rawit dan jeruk nipis serta pembudidayaan ikan lele di KEM Simpang Tiga. Bidang kegiatan yang dilakukan adalah bidang pertanian, peternakan dan perikanan. Efektivitas penyaluran CSR oleh TBBM Sei Siak ini memberikan dampak kepada peningkatan ekonomi kelompok pengelolanya melalui kontribusi penghasilan dari pengelolaan KEM Simpang Tiga.
\end{abstract}

Kata Kunci: Pemberdayaan Masyarakat, Kawasan Ekonomi Masyarakat (KEM), Kelompok Tani Juara, Kelurahan Simpang Tiga

\begin{abstract}
This study presents a descriptive analysis related to the actualization of CSR by PT. PERTAMINA (Persero) MOR I - TBBM Sei Siak on the development of KEM in Simpang Tiga Village located in the City of Pekan Baru. The main objective of this activity is to facilitate members of the Kelompok Tani Juara - the local farmers' community - in managing the use of marginal land in Simpang Tiga Village in Pekan Baru City towards becoming the productive land that has significant economic related-values. The development of the Kelompok Tani Juara as well as local people. Currently, the progress of optimizing the use of KEM Simpang Tiga agricultural land is at the stage of land clearing and planting of Thai chilies and Lime as well as catfish farming EM. Relevant activities were involved including agriculture, livestock and fisheries. The effectiveness of the implementation of CSR by TBBM Sei Siak has an impact on the economic improvement of the management group through the contribution of income gained from the activaties managed in KEM Simpang Tiga.
\end{abstract}

Keywords: Community Empowerment, Community Economic Zone (KEM), Kelompok Tani Juara, TSimpang Tiga Village

\section{PENDAHULUAN}

Kelurahan Simpang Tiga merupakan salah satu kelurahan yang ada di kota Pekanbaru. Di Kelurahan Simpang Tiga ini terdapat kelompok tani yang tingkat ekonomi anggotanya masih menengah kebawah dan tidak memiliki penghasilan serta pekerjaan tetap. Nama kelompok tani adalah Kelompok Tani Juara yang sebagian besar dari mereka merupakan wali murid di SD Juara yang ada di Pekanbaru. Mata pencaharian anggota kelompok tani ini bervariasi antara lain sebagai tukang ojek, tukang pengobatan bekam, jual beli tanaman, peternak ikan lele, ibu rumah tangga, pelukis dan pedagang. Kelompok tani ini berupaya untuk memperbaiki taraf kehidupan ekonominya dengan mencoba meminjam lahan marjinal yang sudah tersedia untuk diolah dan diambil manfaatnya, dengan harapan bisa menambah pendapatan sehingga bisa lebih mandiri dari segi finansial untuk kesejahteraan keluarga. Kelompok Tani Juara telah menggunakan lahan marjinal yang ada di Kelurahan Simpang Tiga untuk memulai usaha pertanian, peternakan dan perikanan.

Usaha meningkatkan perekonomian keluarga Kelompok Tani Juara terkendala faktor utama yaitu modal dan skill. Saat ini pengelolaan lahan pertanian 
sudah pada tahap pembersihan lahan dan penanaman bibit cabe rawit dan jeruk nipis. Akan tetapi karena keterbatasan dana lahan yang sudah dibersihkan dan di cangkul masih belum tertanami. Kendala pengelolaan yang berat saat ini adalah tidak adanya fasilitas alat yang mendukung, sehingga warga hanya menggunakan alat sekedarnya saja untuk membuka lahan. Hal ini menyebabkan lambatnya proses pembukaan lahan,dan tidak optimalnya hasil yang didapat, seperti lahan yang kurang bersih masih menyisakan akar-akar gambut dan area tanam yang belum optimal. Tidak adanya rumah bibit juga menjadi kendala warga KEM sehingga lahan yang sudah siap tanam belum juga tertanami, karena bibit yang disemai kualitasnya tidak baik, dan banyak dirusak oleh binatang peliharaan warga sekitar area pertanian. Disisi lain, kondisi lahan marjinal menjadi semakin tidak produktif dengan kurangnya kompetensi Sumber Daya Manusia (SDM) lokal dalam pembudidayaan bidang perikanan serta akses permodalan yang minim sehingga membatasi ruang gerak komunitas dalam mengaktualisasikan semanat berwirausaha.

Beberapa kondisi minor yang dijelaskan diatas seyogyanya mengandung potensi dan kebermanfaatan ekonomi kepada masyarakat setempat tentunya dengan upaya pembinaan dan pendampingan usaha yang tepat sasaran. Potensi ekonomi inilah yang diwujudkan oleh PT. PERTAMINA (Persero) MOR I - TBBM Sei Siak melalui penyaluran CSR bagi pengembangan Kawasan Ekonomi Masyarakat (KEM) berbasis pemberdayaan masyarkat di Kelurahan Simpang Tiga. Implementasi CSR oleh TBBM Sei Siak ini juga merupakan pengejawantahan tingkatan kepatuhan korporasi khususnya terhadap produk hukum terkait di Indonesia diantaranya:

- UU No. 40 Tahun 2007 tentang Tangungjawab sosial dan Lingkungan (TJSL) UU No 32 tahun 2009 tentang Perlindungan dan Pengelolaan Lingkungan Hidup;

- Peraturan Meneteri Negara BUMN No.PER05/MBU/2007 tentang program kemitraan Badan Usaha Milik Negara (BUMN) dengan usaha kecil dan program bina lingkungan;

- UU No.22 Tahun 2001 tentang pertanggungjawaban BUMN energi dalam pengembangan lingkungan dan masyarakat setempat.

Studi kualitatif dari pelaksanaan CSR oleh PT. PERTAMINA (Persero) MOR I - TBBM Sei Siak memberikan kajian deskriptif tentang efektivitas aktualisasi kegiatan CSR yang dimaksud kepada Kelompok Tani Juara dalam mengelola lahan marjinal yang ada di Kelurahan Simpang Tiga menjadi lahan yang bernilai ekonomi tinggi. Bidang kegiatan yang dilakukan adalah bidang pertanian, peternakan dan perikanan.

\section{HASIL DAN PEMBAHASAN}

\subsection{Desain Kawasan Ekonomi Masyarakat}

Sebelum mulai kegiatan KEM, Kelompok Tani Juara bersama mitra pelaksana yakni FLipMAS Batobo membuat desain KEM yang menggambarkan letak semua komoditas yang akan dibuat di lahan KEM. Pemilihan komoditas yang diadakan di KEM berdasarkan berbagai faktor antara lain kesesuaian jenis tanah, kebutuhan pasar lokal, keberadaan kelompok masyarakat pengelola, dan lain-lain. Semua kegiatan yang memiliki keterkaitan antar komoditas dengan tetap memperhatikan penghasilan harian, mingguan, bulanan dan tahunan.

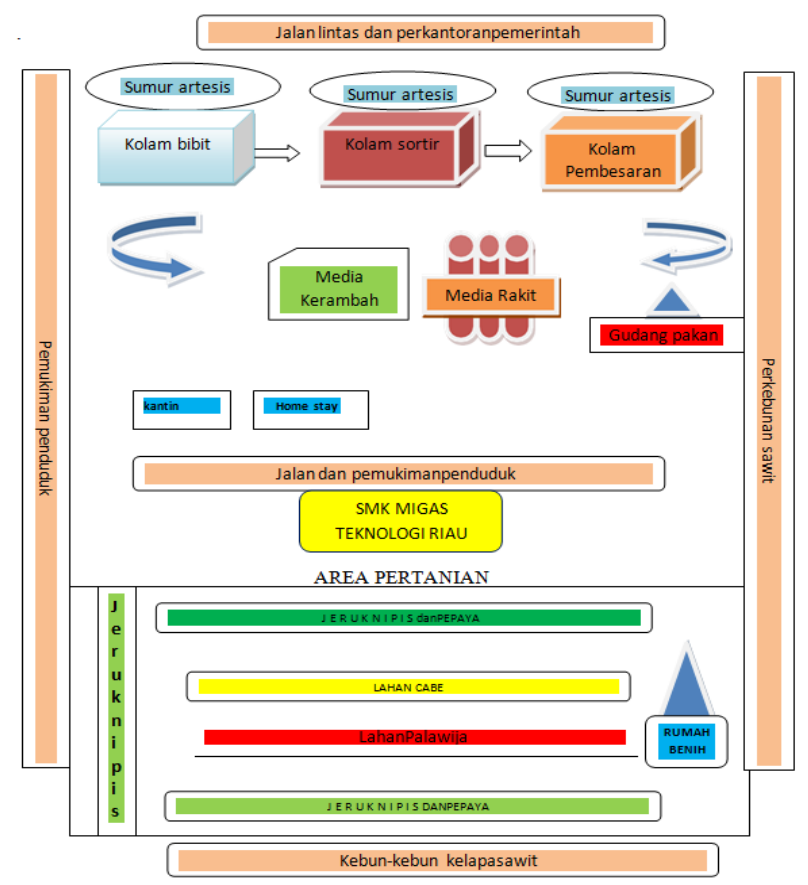

Gambar 1. Tata Letak Komoditas KEM

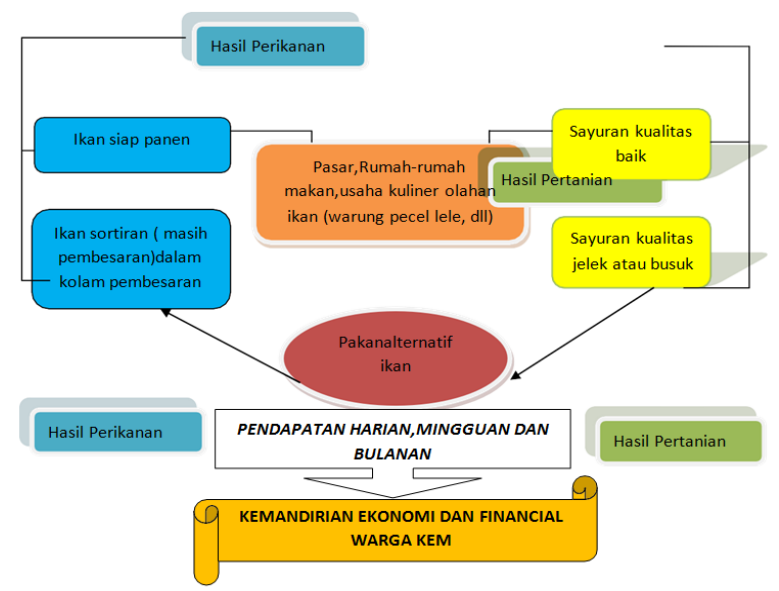

Gambar 2. Diagram Alir Hubungan Antar Komoditas di KEM

Alur hubungan antar komoditas KEM sangat memungkinkan untuk menopang perekonomian warga dengan memaksimalkan pemanfaatan dan pemasaran dari setiap tahap proses komoditas yang di kembangkan seperti terlihat pada Gambar 1.4. Areal KEM berada di sekitar pasar yang buka setiap hari, 
sehingga pemasaran komoditas diperkirakan lebih mudah terlaksana. Hasil panen yang kualitasnya bagus akan dijual ke pasar-pasar yang berada di sekitar wilayah KEM, rumah-rumah makan serta usaha-usaha kuliner olahan ikan.

\subsection{Pembersihan Lahan KEM}

Lahan KEM yang mula-mula masih banyak semak belukar secara berangsur-angsur dibersihkan. Pembersihan lahan dilakukan secara gotong royong oleh anggota Kelompok Tani Juara menggunakan peralatan pertanian yang dibeli dari dana PERTAMINA. Peralatan untuk membersihkan lahan yang dibeli dan digunakan antara lain mesin potong kayu, mesin potong rumput, pisau, cangkul, linggis dan gergaji.

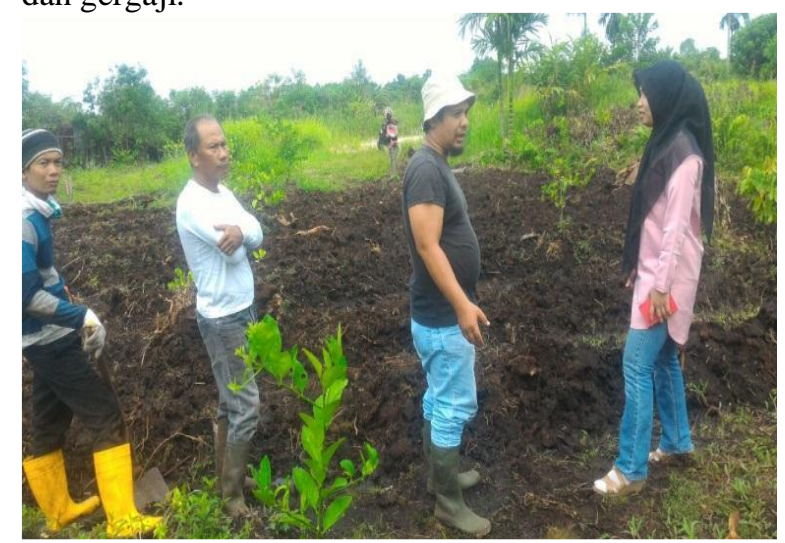

Gambar 3. Proses Pembersihan Lahan KEM

\subsection{Kegiatan KEM}

Kegiatan bidang pertanian terdiri dari:

1) Pembersihan lahan dan pembuatan bedengan,

2) Pembuatan saluran irigasi

3) Pembibitan di dalam rumah bibit dan dipindahkan ke polibag,

4) Pemupukan tanaman menggunakan pupuk urea, NPK dan pupuk kandang.

5) Perawatan, dilakukan setiap hari untuk menghindari tanaman dari gangguan hama dan penyakit.

6) Pemanenan, dilakukan untuk komoditas sayursayuran.

7) Pemasaran, dilakukan dengan menjual langsung ke pasar yang ada di dekat lokasi KEM.

Komoditas yang ditanam di bidang pertanian adalah cabe rawit, kacang panjang, kangkung, seledri, jeruk nipis dan klengkeng.

Kegiatan bidang peternakan terdiri dari:

Pembersihan lahan,

1) Pembuatan kandang ternak yang terdiri kandang kambing dan kandang bebek

2) Pengadaan ternak berupa kambing dan bebek.

3) Penyediaan pakan ternak

4) Perawatan, dilakukan setiap hari untuk menghindari ternak dari penyakit.

5) Pemasaran, dilakukan dengan menjual langsung ke pasar yang ada di dekat lokasi KEM.
Beberapa produk yang telah dipasarkan oleh kelompok bidang peternakan adalah kambing untuk akikah dan telur itik.

Kegiatan bidang perikanan terdiri dari:

1) Pembersihan kolam,

2) Pembuatan kerambah ikan

3) Pembibitan ikan

4) Perawatan dan pemberian pakan

5) Pemanenan

6) Pemasaran

7) Produksi produk hilir ikan lele.

Jenis ikan utama yang dibudidayakan adalah ikan lele. Produk yang dipasarkan adalah lele dengan ukuran tertentu dan sebagian lele dimasukkan ke kolam yang akan dijadikan akan sebagai kolam pancing.

Beberapa produk hilir ikan lele yang telah produksi dan dipasarkan oleh kelompok bidang perikanan adalah abon lele, salai lele dan cincang lele.

\subsection{Analisa Pencapaian Kinerja}

1) Dengan adanya program ini, jumlah penerima manfaat sebanyak 15 orang yang merupakan anggota Kelompok Tani Juara.

2) Dari sisi ekonomi terdapat peningkatan taraf hidup dari $\mathrm{Rp}$ 1.000.000 orang masyarakat dengan pendapatan tambahan dari program senilai $\mathrm{Rp}$ 2.000.000 per bulan.

3) Sebanyak 15 orang mendapatkan peningkatan kesejahteraan.

4) Infrastruktur yang terbangun berupa pondok jaga, kandang kambing, kandang bebek, kerambah ikan

5) Capaian lainnya adalah telah diproduksi produk hilir dari kegiatan ini berupa dendang ikan lele, cincang ikan lele, salai ikan lele, daging kambing untuk akikah.

Berikut adalah hasil KEM Simpang Tiga dalam rentang waktu septetmber 2017 s/d Mei 2018 dengan massa produktif \pm 5 bulan, dengan masing-masing adalah sebahai berikut:

Tabel 1. Kinerja Keuangan 3 (tiga) Sektor KEM Simpang Tiga

\begin{tabular}{|c|l|c|}
\hline No. & \multicolumn{1}{|c|}{ Kelompok } & Total \\
\hline 1 & Pertanian & 5.694 .000 \\
\hline 2 & Perikanan & 29.745 .000 \\
\hline 3 & Peternakan & 3.600 .000 \\
\hline \multicolumn{2}{|c|}{ TOTAL } & 39.039 .000 \\
\hline
\end{tabular}

\subsection{Evaluasi dan Implikasi Capaian}

Kegiatan pembentukan KEM ini telah berjalan dengan baik dan lancar. Hal ini terlihat dari beberapa asfek yaitu:

1. Telah berubahnya lahan yang sebelumnya adalah lahan marjinal menjadi lahan yang bernilai 
ekonomi terutama bagi anggota Kelompok Tani Juara dan pemilik lahan.

2. Ada peningkatan penghasilan anggota Kelompok Tani Juara dari rata-rata Rp 1.000 .000 menjadi Rp 2.000.000. Angka ini diperkirakan akan terus meningkat seiring makin semangat para warga untuk mengelola lahan KEM.

3. Adanya semangat para warga untuk mengelola sesuai arahan dari para prodikmas FlipMAS Batobo untuk meningkatkan skill warga dalam bertani, beternak dan budi daya ikan.

4. Kepedulian walikota Pekanbaru dalam memberi motivasi warga untuk serius dalam mengelola KEM secara langsung ke lokasi KEM.

Beberapa evaluasi dari kegiatan ini adalah:

1. Perlu dikuatkan lagi usaha yang telah warga rintis di lahan KEM, sehingga peningkatan ekonomi mereka akan lebih signifikan. Penguatan ini dapat berupa tambahan dana kegiatan yang berorientasi pada peningkatan nilai jual produk KEM. Misalnya menjadikan kolam ikan yang telah dibuat sebagai tempat rekreasi keluarga di tengah kota. Dengan penguatan ini akan menambah lapangan kerja dan menambah penghasilan warga.

2. Keterlibatan pihak pemerintah perlu di tingkatkan lagi, terutama dukungan terhadap dinas-dinas terkait dalam mengatasi permasalahan budi daya komoditas di lahan KEM. Misalnya keterlibatan penyuluh pertanian, dokter hewan dan ahli perikanan di pemda untuk membantu warga dalam mengelola KEM.

\section{DAFTAR PUSTAKA}

Badan Pusat Statistik. Https://www.bps.go.id

Deswimar, D., \& Almari. (2014). Peran Program Pemberdayaan Masyarakat Desa Dalam Pembangunan Pedesaan. Jurnal El-Riyasah. 5(1), 41-52.

Bagus Fajar Pamungkas, Andi Noor Asikin, Sarwono, Komsanah Sukarti. Pengolahan Pakan Ikan Skala Industri Rumah Tangga Di Marangkayu, Jurnal Flipmas Indonesia

Iwan Suyatna, Aditya Irawan, Dan Moh. Mustakim. Aplikasi Rumpon Untuk Meningkatkan Pendapatan Nelayan Di Pesisir Laut Samboja Kabupaten Kutai Kartanegara, Jurnal Flipmas Indonesia

Andi Noor Asikin, Bagus Fajar Pamungkas, Ita Zuraida, Komsanah Sukarti. Pemanfaatan Ikan Bandeng Duri Lunak Menjadi Aneka Produk Olahan Di Muara Badak, Jurnal Flipmas Indonesia

Soemantri, B. T. (2011). Pedoman Penyelenggaraan Pemerintahan Desa. Bandung: Fokusmedia.

Sulistiyani, A. T. (2004). Kemitraan dan ModelModel Pemberdayaan. Yogyakarta: Penerbit Gava Media.

Qoriah Saleha, Sumoharjo, Erwiantono. Akuaponik Untuk Eksistensi Usaha Pembesaran Ikan Nila Di Kecamatan Loa Kulu, Jurnal Flipmas Indonesia
Phillips, E. N., Berg, M. J., Rodriguez, C., \& Morgan, D. (2010). A case study of participatory action research in a public New England Middle School: Empowerment, constraints and challenges. American Journal of Community Psychology. 46, 179-194. 